УДК 351.74

DOI https://doi.org/10.32837/pyuv.v0i1(30).533

\author{
B. O. Тімашов \\ orcid.org/0000-0001-8368-8856 \\ доктор юридичних наук, доиент, \\ професор кафедри адміністративного, фінансового та інформаиійного права \\ Київського національного торговельно-економічного університету \\ Т. Б. Орлова \\ orcid.org/0000-0001-5406-2432 \\ студентка III курсу факультету міжнародної торгівлі та права \\ Київського національного торговельно-економічного університету
}

\title{
ЗАГАЛЬНІ ЗАСАДИ ЗАБЕЗПЕЧЕННЯ ІНФОРМАЦІЙНОЇ БЕЗПЕКИ ГРОМАДЯН УКРАЇНИ: ПРОБЛЕМИ ТА ПЕРСПЕКТИВИ ВИРІШЕННЯ
}

Постановка проблеми. Захист та успішна реалізація громадянином своїх прав та свобод є основою будь-якого цивілізованого суспільства, кожної демократичної держави.

Беззаперечно, ця аксіома стосується й інформаційної сфери України, а саме захисту прав громадянина у цій сфері та забезпечення безпеки в поширенні інформації.

XXI століття - нова епоха, яка ознаменувалась високим розвитком мобільних технологій, цифрової техніки, мережі Інтернет.

Нині нам складно уявити своє життя без смартфонів, гаджетів, Інтернету. Про це свідчать і дослідження використання сучасних гаджетів. За даними дослідження компанії GfK Ukraine, лише за перше півріччя 2018 року в Україні кількість користувачів смартфонів сягла $85 \%$. Яку ж статистику ми маємо нині, залишається лише припускати. Та, очевидно, відсоток має позитивну динаміку [1]

Постійна потреба в отриманні інформації, доступу, зростання можливостей в інформаційній сфері, з одного боку, суттєво пришвидшує процес становлення інформаційного суспільства із безпосереднім залученням громадян, а з іншого - породжує наскрізну проблему забезпечення інформаційної безпеки громадянина, гарантування захисту в цій сфері.

Отож, метою статті $€$ визначення основоположних засад українського законодавства задля забезпечення інформаційної безпеки кожного громадянина України та висування шляхів вирішення проблем, що пов'язані з ненадійним інформаційним захистом.

Виклад основного матеріалу. Нині визначення поняття інформаційної безпеки, засад національного законодавства в цій сфері, а також проблем, які назрівають у зв'язку із незахищеністю громадянина в інформатизованому глобальному суспільстві є необхідним.

Використання мережі Інтернет, сучасних технологій, нової цифрової техніки супроводжуєть- ся такими явищами, як залежність користувача, низький рівень культури безпеки, кіберзлочинність, поширення небажаного контенту, несанкціонований доступ до інформації та особистих даних, витоки інформації.

Нині надзвичайно важливо знайти баланс між можливостями, які відкриває глобальна інформаційна цивілізація, та ризиками, які виникають перед громадянином як безпосередньо споживачем інформації, саме в контексті державного забезпечення інформаційної безпеки.

Аналіз останніх досліджень із теми, виділення не вирішених раніше частин загальної проблеми, яким присвячується стаття. Визначенню поняття інформаційної безпеки громадянина та дослідженню цієї теми присвятили увагу багато вчених у галузі інформаційного права: К.Л. Бурич, О.В. Глазов, О.Л. Гуровський, О.Г. Данільян, О.П. Дзюбань, О.Н. Караулов, Б.Д. Коган, В.К. Пархоменко, Г.С. Смушков, І.В. Соркін, М.М. Тугай.

Правовою основою регулювання системи забезпечення інформаційної безпеки є Конституція України [2], Закон України «Про інформацію» [3], Закон України «Про Національну програму інформатизації»[4], Закон України «Про Основні засади розвитку інформаційного суспільства в Україні на 2007-2015 роки» [5].

Поняття інформаційної безпеки можна розглядати в багатьох ракурсах. На законодавчому рівні поняття інформаційної безпеки найбільш повно та точно визначалося в Законі України «Про Основні засади розвитку інформаційного суспільства в Україні на 2007-2015 роки». Інформаційна безпека - стан захищеності життєво важливих інтересів людини, суспільства і держави, при якому запобігають завданню шкоди шляхом: неповноти, невчасності та невірогідності інформації, що використовується, негативного інформаційного впливу, негативних наслідків застосування інформаційних технологій, несанкціонованого по- 
ширення, використання і порушення цілісності, конфіденційності та доступності інформації [5].

Основоположним документом нашої держави, Конституцією, в ст. 34 закріплено, що кожному гарантується право на свободу думки і слова, на вільне вираження своїх поглядів і переконань. Окрім цього, в цій статті згадується й про те, що кожному надається право вільно збирати, зберігати, використовувати і поширювати інформацію усно, письмово або в інший спосіб - на свій вибір. Тим самим держава виступає гарантом безперешкодної реалізації та належного захисту інформаційних прав громадян, а значить, і гарантом інформаційної безпеки [2].

Згадані вище положення дають змогу зрозуміти, що кожному громадянину України має бути гарантована інформаційна безпека в разі незаконного доступу до його особистих даних, несанкціонованого збору інформації, а також обмеження права знати, які відомості та з якою метою збираються. Проте тут ми зіштовхуємось із проблемою відсутності чітко прописаного в нормативно-правових актах механізму захисту громадянина та забезпечення його інформаційної безпеки.

У ст. 11 Закону України «Про інформацію» поняття персональних даних (інформації про фізичну особу) визначається як відомості чи сукупність відомостей про фізичну особу, яка ідентифікована або може бути конкретно ідентифікована. Згідно з ч. 2 цієї статті не допускаються збирання, зберігання, використання та поширення конфіденційної інформації про особу без її згоди, крім випадків, визначених законом, і лише в інтересах національної безпеки, економічного добробуту та захисту прав людини [3].

Вироблення та реалізація державної політики у сфері забезпечення інформаційної безпеки передбачає низку принципових ознак та позицій.

Насамперед, правове регулювання інформаційної безпеки тісно пов'язане 3 положеннями норм Конституції України, які передбачають право особи на інформацію як одну зі свобод людини та громадянина, а також із законодавством про інформацію, про забезпечення державної (національної) безпеки, охорону державної та комерційної таємниці, законів, що регулюють діяльність засобів масової інформації, інтернету, питань захисту інформації із обмеженим доступом [2].

Чільне місце в національному законодавстві відведено вищезгаданому Закону України «Про Основні засади розвитку інформаційного суспільства в Україні на 2007-2015 роки» [5].

У загальних положеннях цього нормативно-правового акта законодавцем було окреслено низку проблем, які уповільнюють виведення інформаційного суспільства України на новий рівень, який би відповідав світовим тенденціям.

Водночас Законом України «Про Основні засади розвитку інформаційного суспільства в Україні на
2007-2015 роки» було наведено перелік підходів та стратегічних цілей розвитку інформаційного суспільства в Україні. Однією із зазначених цілей у вищезгаданому законі є покращення стану інформаційної безпеки в умовах використання новітніх інформаційно-комунікаційних технологій [5].

В умовах інтенсивного розвитку глобального інформаційного суспільства, широкого використання інформаційних комп'ютерних технологій у всіх сферах життєдіяльності проблеми інформаційної безпеки набувають особливого значення.

У Декларації принципів «Побудова інформаційного суспільства - глобальне завдання у новому тисячолітті», прийнятій Організацією Об’єднаних Націй 12 грудня 2003 р., зокрема в її п. 35, зазначено: «Зміцнення основи для довіри, у тому числі інформаційна безпека та безпека мереж, аутентифікація, захист недоторканності приватного життя й прав споживачів, є передумовою становлення інформаційного суспільства та зростання довіри з боку користувачів інформаційно-комунікаційних технологій» [6].

Ще одним документом у сфері забезпечення інформаційної безпеки громадян $€$ «Доктрина інформаційної безпеки України» [7].

«Доктрина» визначає пріоритети, які ставить перед собою державна політика в інформаційній сфері в умовах гібридної війни. Серед великого переліку стратегічних цілей та завдань, спрямованих на захист кордонів, територіальної цілісності держави, знаходимо положення щодо захисту громадянина в інформаційному суспільстві через нестабільну ситуацію в державі: «законодавче врегулювання механізму виявлення, фіксації, блокування та видалення 3 інформаційного простору держави, зокрема з українського сегмента мережі Інтернет, інформації, яка загрожує життю, здоров'ю громадян України <...>» [7].

Аналіз українського законодавства в галузі інформаційного права наштовхує на думку, що більшість заходів, цілей, методів, стратегій у сфері інформаційної безпеки спрямовані, насамперед, на захист держави, ㄲï територіальної цілісності та суверенітету. Ця необхідність підсилюється ще й умовами військових дій на сході України. Водночас громадянин залишається законодавчо незахищеним у період посиненої глобалізації інформаційного суспільства.

На жаль, в українському законодавстві відсутні конкретні засади (принципи), які б змогли гарантувати особі захист у разі незаконного порушення доступу до персональних даних, приховування факту збору відомостей про особу.

Ми зіштовхуємось із проблемою відсутності конкретного нормативного акта, де було б прописане наше право на інформаційну безпеку. Натоміть відповіді доводиться шукати в інших законах чи підзаконних актах. Так, у ст. 188-39 Кодексу 
України про адміністративні правопорушення (далі - КУпАП) йдеться про відповідальність особи в разі порушення законодавства у сфері захисту персональних даних [8].

Ст. 182 Кримінального кодексу України передбачено штраф, виправні роботи, арешт або обмеженням волі в разі порушення недоторканості приватного життя громадян, а саме: незаконного збирання, зберігання, використання, знищення, поширення конфіденційної інформації про особу або незаконна зміна такої інформації [9].

Окремі положення нормативно-правових актів вказують на забезпечення інформаційної безпеки як одну із пріоритетних цілей державної політики, проте разом із тим не визначають, яким чином ця політика реалізуватиметься. Як наслідок, нині в Україні відсутній конкретний законодавчо закріплений механізм реалізації політики у сфері забезпечення інформаційної безпеки громадянина.

Документи являють собою сукупності теоретичних понять інформаційної безпеки громадянина, але чітких завдань, механізму, відповідальних суб'єктів за її забезпечення не наводять.

Досвід європейських держав у становленні інформаційного суспільства демонструе нам ефективність реалізації стратегії інформаційної та кібербезпеки шляхом комплексного охоплення інформаційної безпеки починаючи від глобального, тобто рівня держави до одиничного - людини як користувача мережі. Так, наприклад, побудоване інформаційне законодавство в Данії [10].

Нині проблеми інформаційної безпеки особи стають провідною темою наукових розробок та напрацювань, де вказується про важливість інформаційного виховання та необхідність закладення основ інформаційної безпеки на початкових етапах формування особистості. Успішна реалізація заходів інформаційної безпеки особистості можлива лише за умови принципово нових підходів до системи освіти, а також методів передачі й формування масивів знань. Учені доходять висновку про необхідність переходу до нової стратегії розвитку сучасної системи освіти, в основу якої покладена ідея випереджаючої освіти [11, с. 245].

Висновки. Враховуючи низку проблем та прогалин у національному законодавстві у сфері інформаційної безпеки, насамкінець, хочеться проаналізувати перспективи та шляхи вирішення цих проблем.

По-перше, законодавство має бути максимально доступним та адаптованим для громадянина, а це означає, що нині є необхідність прийняти комплексний системний нормативно-правовий акт, який би конкретно формулював основні засади щодо захисту інформаційної безпеки громадян та наводив чіткий механізм державного захисту громадянина.

По-друге, мають бути встановлені норми та юридичні механізми системи, яка б визначила захист інформації в державі та забезпечила б відповідний механізм, що попередив би посягання на інформаційну безпеку.

По-третє, необхідне визначення конкретного кола суб'єктів, які б дбали про інформаційну безпеку населення.

По-четверте, потрібне збільшення освітнього рівня та рівня особистої обізнаності громадян у сфері захисту особистої інформації та інформаційної безпеки.

По-п’яте, необхідні адаптація українського законодавства до законодавства європейських держав та врахування іноземного досвіду у становленні інформаційного суспільства, де громадянин та його інформаційні права є захищеними.

Отже, нині питання інформаційної безпеки громадянина є особливо актуальним, адже в умовах всесвітньої глобалізації, становлення інформаційного суспільства, гібридної війни проблема захищеності громадянина постає ще більш гостро та потребує швидких та негайних дій і рішень із боку держави та ефективної державної політики у сфері інформаційної безпеки.

Удосконалення законодавства, затвердження основоположних засад, створення реальних стратегій забезпечення інформаційної безпеки громадян та плану їх реалізації, модернізація застарілих підходів, нове технічне обладнання, а також успішний іноземний досвід в інформаційній сфері та запровадження дієвих освітніх заходів задля підвищення інформаційної грамотності осіб дадуть змогу Україні стати гідним конкурентом на міжнародному інформаційному ринку.

\section{Jimepamypa}

1. Спецпроект компанії GfK Ukraine. Київ, 2018. URL: https://www.gfk.com/uk-ua/.

2. Конституція України : Закон України від 28 червня 1996 р. № 254к/96-ВР Відомості Верховної Ради України. 1996. № 30. URL: https://zakon.rada.gov.ua/ laws/show $/ 254 \%$ D0 \% BA $/ 96-\%$ D0 \% B2\% D1 \% 80 (дата звернення: $18.03 .2020 \mathrm{p}$.).

3. Про Національну програму інформатизації : Закон України від 04.02.1998 p. № 27-28. URL: https://zakon.rada.gov.ua/laws/show/74/98-\% D0\% B2\% D1\% 80 (дата звернення: 18.03 .2020 р.).

4. Про інформацію : Закон України від 02.10.1992 p. № 48. URL: https://zakon.rada.gov.ua/laws/ show/2657-12. (дата звернення: 18.03 .2020 р.).

5. Про Основні засади розвитку інформаційного суспільства в Україні на 2007-2015 роки : Закон України від 9 січня 2007 р. № 12. URL: https://zakon.rada.gov.ua/laws/show/537-16. (дата звернення: $18.03 .2020 \mathrm{p}$.).

6. Декларація принципів «Побудова інформаційного суспільства - глобальне завдання у новому тисячолітті" : прийнята та проголошена Організацією Об’єднаних націй від 12 грудня 2003 р. Базаданих «Законодавство України». URL: https://zakon.rada.gov.ua/ laws/show/995_c57. (дата звернення: 20.03.2020 p.).

7. Доктрина інформаційної безпеки України : Указ Президента України про рішення Ради національної 
безпеки і оборони України від 29 грудня 2016 р. «Про Доктрину інформаційної безпеки України" № 47. URL: https://zakon.rada.gov.ua/laws/show/47/2017. (дата звернення: 20.03 .2020 р.).

8. Кодекс України про адміністративні правопорушення : Закон України від 17.12.1984 р. № 51. URL: https://zakon.rada.gov.ua/laws/show/80731-10. (дата звернення: 20.03 .2020 р.).

9. Кримінальний кодекс України : Закон України від 05.04.2001 p. № 25-26. URL: https://zakon.rada.gov.ua/ laws/show/2341-14. (дата звернення: 20.03.2020р.).

10. Danish Cyber and Information Security Strategy. May 2018. URL: https://en.digst.dk/media/17189/ danish_cyber_and_information security_strategy_pdf. pdf . (дата звернення: 20.03.2020 р.)

11. Жарков Я.М. Інформаційна безпека особистості, суспільства, держави : підручник. Київ : КНУ ім. Т.Г. Шевченка, 2008. 274 с.

\section{Анотація}

Тімашов В. О., Орлова Т. Б. Загальні засади забезпечення інформаційної безпеки громадян України: проблеми та перспективи вирішення. - Стаття.

Ця стаття присвячується аналізу українського законодавства та державної політики щодо забезпечення інформаційної безпеки громадян України, визначенню юридичного механізму захисту громадян у разі порушення інформаційних прав, пошуку шляхів вирішення проблем у сфері інформаційної безпеки осіб.

$\mathrm{y}$ роботі на основі дослідження українського законодавства та наукових напрацювань із інформаційного права було наведено визначення поняття інформаційної безпеки та зумовлено необхідність подальшого розвитку та удосконалення законодавства, 3 огляду на умови сьогодення, зокрема світову інформаційну глобалізацію, до якої залучена Україна.

Також було проаналізовано заходи, які здійснюються в межах державної інформаційної політики, яка спрямована на забезпечення вільного доступу до інформації, безперешкодного її отримання, зберігання, використання та охорони, а також інформаційного захисту населення.

Нами було наведено основні засади, на які направлено вектор національної політики в умовах становлення інформаційного суспільства в Україні.

Під час аналізу нормативно-правових актів у сфеpi забезпечення інформаційної безпеки громадян було виведено низку прогалин у сучасному законодавстві, що пов'язані із захистом громадян України у зв'язку iз несанкціонованим доступом до конфіденційної інформації та збором відомостей.

Також у дослідженні було проаналізовано наукові напрацювання у сфері захисту інформаційної безпеки громадян та визначено важливість підвищення інформаційної свідомості кожної особистості, застосування новітніх підходів до системи освіти, вжиття заходів, які б сприяли цьому процесу.
На основі досліджених матеріалів було сформульовано пропозиції удосконалення юридичного механізму захисту громадян у разі порушення інформаційних прав, запропоновано шляхи вирішення проблем у сфері інформаційної безпеки осіб та передбачено перспективи розвитку українського законодавства.

Ключові слова: інформація, інформаційне суспільство, всесвітня глобалізація, інформаційна безпека, державна інформаційна політика, право на інформацію, стратегія розвитку, інформаційний простір.

\section{Summary}

Timashov V. A., Orlova T. B. General principles of information security of Ukrainian citizens: problems and prospects for solution. - Article.

This article is devoted to the analysis of Ukrainian legislation and state policy on ensuring information security of Ukrainian citizens, defining the legal mechanism of protection of citizens in case of violation of information rights, finding ways to solve problems in the field of information security of persons.

The work, based on the study of Ukrainian legislation and scientific developments in information law, defines the concept of information security and identifies the need for further development and improvement of legislation, taking into account the current conditions, in particular the global information globalization, which Ukraine is involved in.

It also analyzed measures implemented within the framework of the state information policy aimed at ensuring free access to information, free access to information, storage, use and protection, as well as information protection of the population.

We have outlined the basic principles to which the vector of national policy is directed in the conditions of formation of the information society in Ukraine.

During the analysis of legal acts in the field of information security of citizens, a number of gaps in the current legislation were identified, which related to the protection of citizens of Ukraine in connection with the unauthorized access to confidential information and the collection of information.

Also, this study analyzed scientific developments in the field of information security of citizens and identified the importance of raising the awareness of each person, applying the latest approaches in the education system, conducting activities that would contribute to this process.

On the basis of the researched materials, proposals for improvement of the legal mechanism of protection of citizens in case of violation of information rights were formulated, ways of solving problems in the field of information security of persons were proposed, and prospects for the development of Ukrainian legislation were provided.

Key words: information, information society, world globalization, information security, state information policy, right to information, development strategy, information space. 